\title{
Antibacterial effect of pineapple (Ananas comosus) extract towards Staphylococcus aureus
}

\author{
Yong Ker Loon*, Mieke Hemiawati Satari**, Warta Dewi** \\ *Yong Dental Surgery Kuala Lumpur, Malaysia \\ **Department of Oral Biology Faculty of Dentistry Universitas Padjadjaran, Indonesia
}

\section{ABSTRACT}

Introduction: Staphylococcus aureus is one of the important medical pathogens which have been recognised for many years as a remedy for a wide case of oral infections. Nowadays, the use of herbal remedy for reducing bacteria in the oral cavity has been implemented widely due to the fewer side effects. Therefore, researchers have been finding ways to use pineapple in dentistry to prevent many cases of oral diseases. The purpose of this study was to prove that pineapple extract in different concentration had the potential as an antibacterial agent towards Staphylococcus aureus. Methods: The study was an experimental laboratory conducted by determining the minimum inhibitory concentration of pineapple (Ananas comosus) with the two-fold serial dilution methods. Results: The The Minimum Inhibitory Concentration (MIC) of the pineapple extract was 1.56\%-0.78\%. Conclusion: The pineapple extract had an antibacterial effect towards Staphylococcus aureus due to the bromelain compound and its phytochemical factor such as Vitamin $\mathrm{C}$ and flavonoid.

Keywords: Antibacterial effect, Minimum Inhibitory Concentration (MIC), pineapple extract, Staphylococcus aureus.

P-ISSN 1979-0201, e-ISSN 2549-6212 Available from: http://jurnal.unpad.ac.id/pjd/article/view/16099

DOI: 10.24198/pid.vol30no1.16099

Submission: Dec 2017 Publishing: Mar 2018

\section{INTRODUCTION}

There are lots of bacteria species of the oral cavity, and most of them are opportunistic bacteria commonly found causing disease in immunocompromised patients. In the past few years, S. aureus has become an important medical pathogen which has been recognised for many years as the aetiology of a wide case of oral infections included; angular cheilitis, root canals infection, facial cellulitis, osteomyelitis of the jaws, parotitis, stomatitis, gingivitis, and dentoalveolar abscesses. ${ }^{1}$

The antibacterial agent often used to eliminate the amount of S.aureus in the form of mouthwash consists of substances that might have many negative side effects towards the oral health, for example, discolouration of teeth \& tongue, and change in taste $\&$ sensation as seen in the use of chlorhexidine. ${ }^{2}$ 
Nowadays, researchers have tried to use fruits for dental health to prevent oral diseases. One of them is pineapple (Ananas comosus) that contains vitamin $C$, and flavonoids which have antimicrobials ${ }^{3}$, effects including some foodborne pathogens. ${ }^{4}$

Furthermore, pineapples also have one important compound called bromelain which is obtained from either the stem or the fruit of pineapples, which plays important roles in health. Recently, researchers had suggestions that bromelain may exhibit the antibacterial activity, as well as antiviral. In fact, several studies have shown that bromelain inhibited certain viruses and bacteria in-vitro. Bromelain as an antiseptic showed good results in many experimental laboratory research. Some researchers have shown evidence that the fruit supplement was able to cure these infectious agents and may prove to be a useful adjunctive therapy for bronchitis, pneumonia, and urinary tract infections. ${ }^{5}$ The antibacterial effects may also help controlling diarrhoea caused by bacteria. ${ }^{5}$ The purpose of this study was to prove the antibacterial potential of the pineapple extract in different concentration towards S.aureus.

\section{METHODS}

This study was an experimental laboratory. The materials used were pineapple extracts in the liquid form, Staphylococcus aureus, glucosebouillon liquid medium, nutrient agar plate, acetone $80 \%$, phosphate with $\mathrm{pH} 7.5$, casein $1 \%$, and trichloroacetic solution $30 \%$.

The tools used in this study were laboratory apparatus used for bacterial culture, microscope, reaction tubes, tube rack, pipette, inoculums, object glass, glass marking pencil, Bunsen burner, incubator, Soxhlet extraction tools, bowls, blender, centrifuge, freeze dryer, $\mathrm{pH}$ meter, analytical balance, spatula, and glass stirrer.

Bacteria isolation was performed by identifying Staphylococcus aureus grown on the blood agar. Complete hemolysis of erythrocytes with golden pigmentation around the colony with round, convex, with a diameter of $1-4 \mathrm{~mm}$, and a sharp border were found on the blood agar. ${ }^{5}$

The preparation of the pineapple extract was performed with the procedure as follows: the pineapple pulp was cut into small pieces, blended, pressed, then filtered, to obtain a clear liquid extract. Then acetone was added to this solution with the ratio of $1: 4$. Afterwards, idled the solution overnight at $10^{\circ} \mathrm{C}$ to precipitate the enzyme. The solution was centrifuged at the speed of $15.000 \mathrm{rpm}$ for 15 minutes at $10^{\circ} \mathrm{C}$. The precipitation result obtained was then freeze dried. The extract in the powder form containing bromelain was kept under the temperature of $4^{\circ} \mathrm{C}$, then dissolved in the phosphate solution as a buffer at the $\mathrm{pH}$ of 7.5. ${ }^{5}$

The bromelain enzyme activity was determined by the Murachi method using casein substrate. The total of $1 \mathrm{ml}$ of casein $(20 \mathrm{mg} /$ $\mathrm{ml}$ ) was added towards $2 \mathrm{ml}$ of pineapple extract in a buffer solution with the $\mathrm{pH}$ of 7.5 , and 25 times dilution. Afterwards, the solution was incubated at the temperature of $55^{\circ} \mathrm{C}$ for 15 minutes. After incubation, the mixture solution was added with $1 \mathrm{ml}$ of $30 \%$ trichloroacetic acid solution. Coagulated proteins were separated by centrifugation. The filtrate obtained was then measured by the absorbance at the wavelength of $280 \mathrm{~nm}$. Activity unit was the amount of enzyme caused an increasing value of $0.001 \mathrm{~A}$ unit/minute in Blanko. ${ }^{5}$

The Blanko was used as a phosphate buffer solution at the $\mathrm{pH}$ of 7.5 and used as the control enzyme activity. The control enzyme was heated and treated similarly to the above procedure. ${ }^{5}$ The Minimum Inhibitory Concentration (MIC) was the lowest concentration level of the pineapple extract needed to inhibit the growth of Staphylococcus aureus based on a serial of twofold dilution method.

The two-fold dilution method was performed using as much as 10 test tubes. First, a micropipette was used to dispense $2 \mathrm{ml}$ of glucose-bouillon liquid medium to the test tube number 2-8. Then as much as $4 \mathrm{ml}$ of pineapple extract was placed in tube number 1 with the concentration of $100 \%$. Afterwards, the same micropipette was used to transfer as much as 2 $\mathrm{ml}$ of pineapple extract from test tube number 1 into the test tube number 2 , then diluted in the glucose-bouillon liquid medium inside the test tube number 2 to make the concentrated extract of $50 \%$. This serial was the first stage of two-fold dilutions. 
Next, the same micropipette was used to carry out the second stage of two-fold dilution, which was the $2 \mathrm{ml}$ of solution from test tube number 2 into the test tube number 3 . The solution in the test tube number 3 was stirred to get the $25 \%$ concentration. As much as $2 \mathrm{ml}$ of the $25 \%$ concentration solution was taken from test tube number 3 and inserted into test tube number 4 then stirred to get the 12.5\% concentrated solution. From test tube number 4 , as much as $2 \mathrm{ml}$ solution was taken and inserted into test tube number 5 then stirred to get the $6.25 \%$ concentrated solution; the same steps were repeated for the next test tube until the $3.12 \%$ concentrated solution in the test tube 6 , the $1.56 \%$ concentrated solution in the test tube number 7 , and the $0.78 \%$ concentrated solution in the test tube number 8 were obtained.

Test tube number 9 was filled with $2 \mathrm{ml}$ of solution from test tube number 8 as the negative control solution, and the test tube number 10 was filled with $2 \mathrm{ml}$ of glucose-bouillon liquid medium added with the $S$. aureus suspension as the positive control solution (Fig. 1).

$0.1 \mathrm{ml}$ of Staphylococcus aureus suspension was added into the test tube number $1-8$, and 10 with bacterial turbidity in accordance with $M C$ Farland standard of 0.5 . In the microbiology field, McFarland standards are used as a reference to adjust the turbidity of bacterial suspension to control the amount of bacteria within a given range. The test tube number 1-10 were then incubated at the temperature of $37^{\circ} \mathrm{C}$ for 24 hours in aerobic condition.

The lowest concentration of the pineapple extract that inhibited the bacterial growth was determined as the minimum inhibitory concentration. The turbidity that indicates the bacterial growth sometimes invisible to the naked eyes, therefore, to ascertain the bacterial growth in each test tube; one loopful of the solution was streaked on a nutrient agar plate and incubated at the temperature of $37^{\circ} \mathrm{C}$ for 24 hours. If no amount of bacterial growth on the nutrient agar plate was observed, then the certain concentration had inhibited the bacterial growth.

\section{RESULTS}

Bacterial isolation was performed by identifying the S.aureus growth on the blood agar (Fig. 2). Hemolysis of erythrocytes with golden pigmentation around the colony with a round and convex shape and having a diameter of $1-4 \mathrm{~mm}$ with a sharp border was observed on the blood agar.

The two-fold dilution method (Fig. 3) was performed to produce different concentration of pineapple extract (100\%; $50 \%$; $25 \%$; $12.5 \%$; $6.25 \%$; $3.125 \%$; $1.56 \%$; and $0.78 \%$ ) (Tab. 1 ). The results showed that at the concentration of $100 \%, 50 \%$,

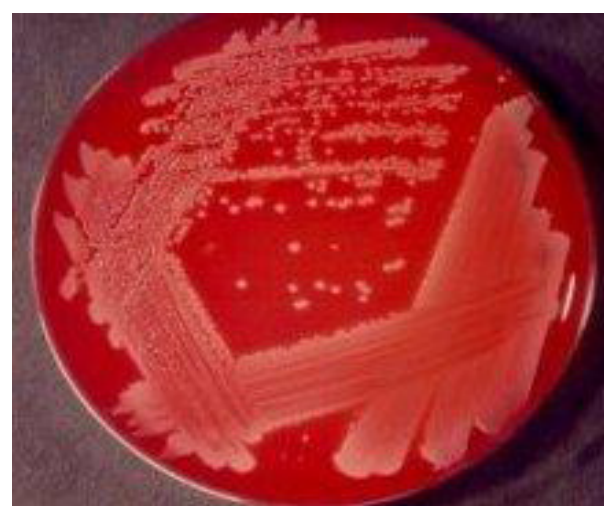

Figure 2. Staphylococcus aureus

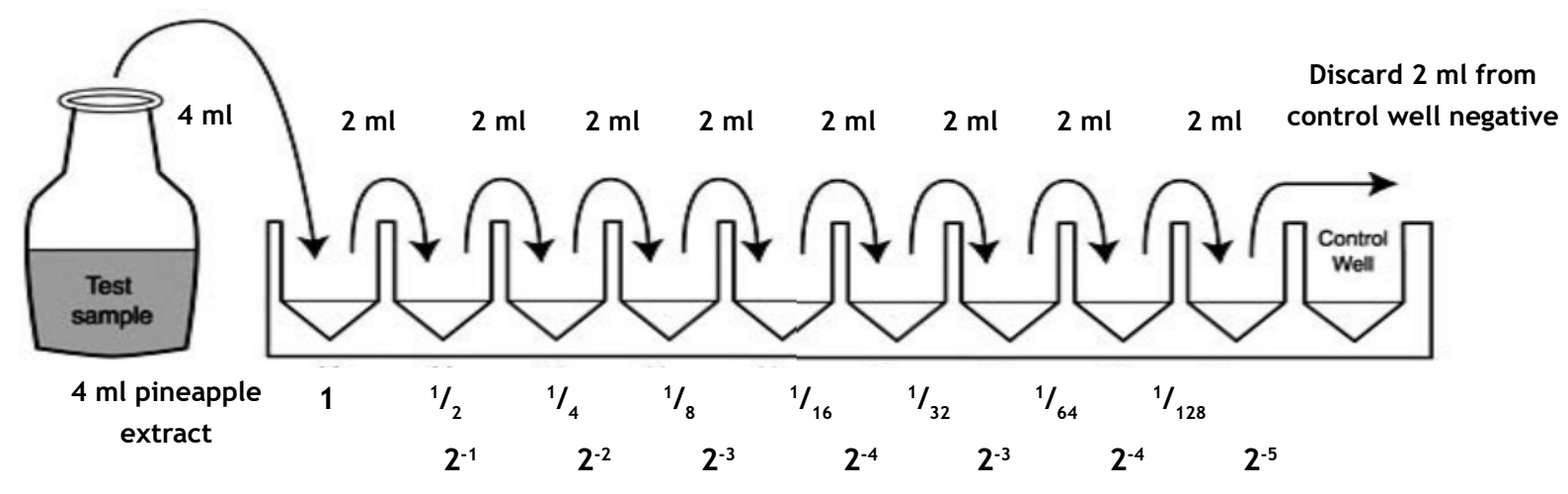

Figure 1. The serial of two-fold dilution 


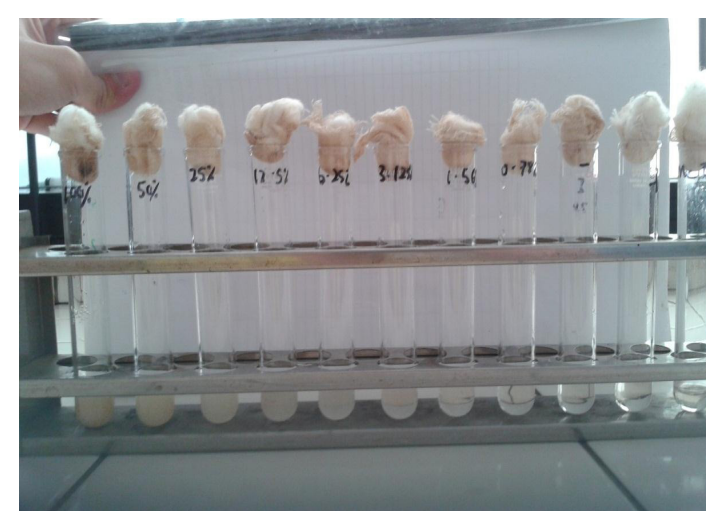

Figure 3. The two-fold dilution method

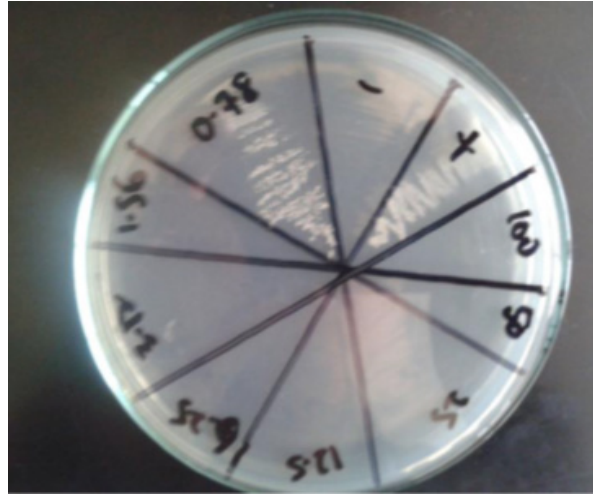

Figure 4. Sectoral implantation

Table 1. Serial dilutions performed on three bacteria sample with three times repetitions

\begin{tabular}{ccccccccccc}
\hline Sample & $100 \%$ & $50 \%$ & $25 \%$ & $12.5 \%$ & $6.25 \%$ & $3.12 \%$ & $1.56 \%$ & $0.78 \%$ & $\mathrm{NC}$ & $\mathrm{PC}$ \\
\hline 1 & - & - & - & - & - & - & - & + & - & + \\
& - & - & - & - & - & - & - & + & - & + \\
& - & - & - & - & - & - & - & + & - & + \\
2 & - & - & - & - & - & - & - & + & - & + \\
& - & - & - & - & - & - & - & + & - & + \\
3 & - & - & - & - & - & - & - & + & - & + \\
& - & - & - & - & - & - & - & + & - & + \\
& - & - & - & - & - & - & - & + & - & + \\
& - & - & - & - & - & - & - & + & - & + \\
\hline
\end{tabular}

*- No growth; + Growth present, *NC = negative control; PC = positive control

$25 \%, 12.5 \%, 6.25 \%, 3.12 \%$ and $1.56 \%$, the sample number 1-3 showed negative results, meaning no presence of bacterial growth. Alower concentration of $0.78 \%$ showed positive results where bacterial growth was observed. The test tube number 9 was the negative control that showed the negative antibacterial result, and the test tube number 10 was the positive control and showed the presence of bacterial growth. The absence of the bacterial growth could be estimated by examining the turbidity of the suspension, but a sectoral culture must be performed to ascertain the presence of the bacteria (Fig. 4).

The results also showed that the pineapple extract in the test tube number $1-7$ \& 9 were showing no presence of bacterial growth, whilst the extract in the test tube number 8 \& 10 were turbid thus showed the presence of bacterial growth (Fig. 3). From the sectoral culture examination was showed that there was no presence of bacterial growth on the test tube number 1-7 \& 9 sectors (Fig. 4).

\section{DISCUSSION}

The results of this study suggested that the lowest concentration which able to inhibit the bacterial growth was $1.56 \%$, whilst at the concentration of $0.78 \%$, the bacterial growth was present. This result means that the Minimum Inhibitory Concentration (MIC) value was in the range of $1.56 \%-0.78 \%$. Further research was needed to determine the exact MIC value. Based on the result shown in Table 1, the pineapple extract was having an antibacterial effect. However, further research was still needed before applying the pineapple extract as an oral disease medication.

The main antibacterial properties of the pineapple extract was contributed by the bromelain which was the proteolytic enzyme compound, the acidity of pineapple extract, and the phytochemical factor (flavonoids and vitamin C). Bromelain as the proteolytic enzyme plays an important role in the protein catabolism of the bacteria, mainly the peptidoglycan cell wall. 
Interaction with the bacterial cell wall affected the membrane permeability, thus resulting in mortal damage towards the cell. ${ }^{6}$ The enzyme was also dissolved or ingested the antigens which cause the auto-immune response thus protecting the body from the presence of the bacterial agents either in the digestion, the intestines, or in the blood circulation.

Furthermore, bromelain also promotes the absorption of antibiotic thus capable of enhancing the tissue permeability of Penicillins and Tetracyclines after oral administration. The absorption increase leads to an improved diffusion of antibiotics and also apparently maintaining the antibiotics effect in the system longer. ${ }^{7}$

Bromelain is also able to modulate the cellimmunity function. Many research had shown that the production of these cytokines from leukocytes after the administration of Bromelain played an important role in the communication during normal immunological response where it signalled and activated the macrophages to response towards bacteria's antigen as well as under the infection, inflammatory, and neoplastic states. ${ }^{8}$ Moreover, granulocytes reacted to the same compound by forming a reactive oxygen radical with the antimicrobial effect. ${ }^{7}$

There are more than thousands of wellknown phytochemicals, and two of the most commonly found in pineapple are polyphenol antioxidants such as flavonoids and Vitamin C. ${ }^{9}$ These phenols have the ability to denatures the protein. Phenol was also lipophilic that attracted to lipid molecules contained in the cell membranes. The more lipophilic the flavonoid, the higher greater damage to the bacterial cell membrane will occur and break down the bacterial cell component that leads to the cell death. ${ }^{8}$

Vitamin C kills the bacterial agent by creating an inhospitable environment for the bacterial growth $(\mathrm{pH}<4)$, where the majority bacteria grow on the $\mathrm{pH}$ range from 7.0-7.5, with the minimum $\mathrm{pH}$ was $4.5 .{ }^{10}$ If the external environment $\mathrm{pH}$ was low, the concentration of $\mathrm{H}^{+}$ion will be higher in the external environment than in the internal environment thus the $\mathrm{H}^{+}$ion will move into the cytoplasm with the lower cytoplasmic pH. Drastic variations in the cytoplasmic $\mathrm{pH}$ were able to damage the microorganisms by disrupting the plasma membrane or inhibiting the activity of enzymes and membrane protein transport. Most prokaryotes will die if the internal $\mathrm{pH}$ drops far below 5.0-5.5. ${ }^{10}$

Vitamin $C$ also helps to neutralise the toxins produced by the bacterial agent, and also strengthens and protects the immune system by stimulating the activity of antibodies and the immune system cells such as phagocytes and neutrophils. The antibody systems are unable to eradicate bacteria without the assistance of vitamin C. ${ }^{11}$

\section{CONCLUSION}

Pineapple extract had an antibacterial effect towards Staphylococcus aureus due to bromelain as the active compound, and the phytochemical factors such as Vitamin C and flavonoid.

\section{REFERENCES}

1. Smith AJ, Jackson MS, Bagg J. The ecology of Staphylococcus species in the oral cavity. J Med Microbiol. 2001 Nov;50(11):940-6. DOI: 10.1099/0022-1317-50-11-940

2. Slots J. Selection of antimicrobial agents in periodontal therapy. J Periodontal Res. 2002 Oct;37(5):389-98.

3. Vattem DA, Lin YT, Labbe RG, Shetty $K$. Phenolic antioxidant mobilization in cranberry pomace and effect on antimicrobial activity against selected food borne pathogens. Innov Food Sci Emer Tech. 2004 Mar;5(1):81-91. DOI: 10.1016/j.ifset.2003.09.002

4. Mishra N, Dubey A, Singh N, Gupta P. Antimicrobial, antioxidant and chemopreventive potential of Vitamin C rich fruits. Int J Appl Biol Pharm Tech. 2010 NovDec;1(3):915-920.

5. Mynott TL, Guandalini S, Raimondi F, Fasano A. Bromelain prevents secretion caused by Vibrio cholera and Esherichia coli enterotoxins in rabbit ileum in vitro. Gastroenterology. 1997 Jul;113(1):175-84.

6. Mynott TL, Guandalini S, Raimondi F, Fasano A. Bromelain prevents secretion caused by Vibrio 
cholera and Esherichia coli enterotoxins in rabbit ileum in vitro. Gastroenterology. 1997 Jul;113(1):175-84.

7. Ezine Articles [homepage on internet]. Fitzgerald PS. 2010. Protease enzyme aid in preventing food allergies. [cited 2012 Aug] [about 2 screens]. Available from: http://EzineArticles.com/expert/Paul_S_ Fitzgerald/231115

8. Maurer HR. Bromelain: biochemistry, pharmacology and medical use. Cell Mol Life Sci. 2001 Aug;58(9):1234-45. DOI: 10.1007/ PL00000936

9. Kelly GS. Bromelain: A literature review and discussion of its therapeutic applications. Alt Med Rev. 2006;1(4):243-57.

10. The Caribbean Food \& Nutrition Institute [homepage on internet]. Burrello. 2005. Phytochemicals. [cited 2012 Aug] [about 2 screens]. Available from: http://www.paho/ cfni.org

11. Manimozhi DM, Sankaranarayanan S, Sampathkumar G. Evaluating the antibacterial activity of flavonoids extracted from Ficus benghalensis. Int J Pharm Biol Res. 2012 FebMar;3(1):7-18.

12. Food Doctors [homepage on internet]. Eigenaar. 2008. The food safety file: Staphylococcus aureus. [cited 2012 Sep] [about 3 screens]. Available from: http:// www.fooddoctors.com/FSF/S_ aureus.pdf

13. McGraw Hill Higher Education [homepage on internet]. Ingraham JL. 2007. Microbial growth. [cited 2012 Aug] [about 5 screens]. Available from: http://highered.mcgraw-hill. com/sites/dl/free/0.pdf

14. Iqbal K, Khan A, Khattak MAK. Biological significance of ascorbic acid (vitamin C) in human health - A review. Pakistan J Nutr. 2004;3(1):5-13. 